Article

\title{
Dnd1 Knockout in Sturgeons By CRISPR/Cas9 Generates Germ Cell Free Host for Surrogate Production
}

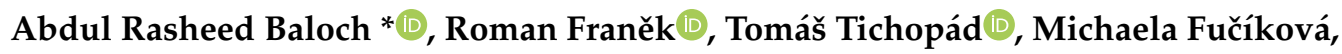 \\ Marek Rodina and Martin Pšenička \\ Faculty of Fisheries and Protection of Waters, South Bohemian Research Center of Aquaculture and Biodiversity \\ of Hydrocenoses, University of South Bohemia in Ceske Budejovice, Zátiší 728/II, 38925 Vodňany, Czech \\ Republic; franek@frov.jcu.cz (R.F.); tichopad@frov.jcu.cz (T.T.); fucikova@frov.jcu.cz (M.F.); \\ rodina@frov.jcu.cz (M.R.); psenicka@frov.jcu.cz (M.P.) \\ * Correspondence: baloch@frov.jcu.cz; Tel.: +420-38777-4784
}

Received: 14 March 2019; Accepted: 12 April 2019; Published: 17 April 2019

check for updates

Simple Summary: Sturgeons, also called archaic giants, are critically endangered fish species due to overfishing for caviar and interference in their natural habitats. Some sturgeon species have life spans of over 100 years and sexual maturity is attained between 20 to 25 years. Sterlet (Acipenser ruthenus) has fastest reproductive cycle; thus, this species can be used for surrogate production in sturgeons. Primordial germ cells are the origin of all germ cells in developing embryos. Dnd1 is essential for formation and migration of primordial germ cells and its inactivation results in sterility in fish. In our study, we have used a cutting-edge genome editing technology known as CRISPR/Cas9 to knockout $d n d 1$ and to prepare a sterile sterlet host. CRISPR/Cas9 knocked-out embryos lacked primordial germ cells and can be used as a sterile host for surrogate production in sturgeons.

Abstract: Sturgeons also known as living fossils are facing threats to their survival due to overfishing and interference in natural habitats. Sterlet (Acipenser ruthenus) due to its rapid reproductive cycle and small body size can be used as a sterile host for surrogate production for late maturing and large sturgeon species. Dead end protein (dnd1) is essential for migration of Primordial Germ Cells (PGCs), the origin of all germ cells in developing embryos. Knockout or knockdown of $d n d 1$ can be done in order to mismigrate PGCs. Previously we have used MO and UV for the aforementioned purpose, and in our present study we have used CRISPR/Cas9 technology to knockout $d n d 1$. No or a smaller number of PGCs were detected in crispants, and we also observed malformations in some CRISPR/Cas9 injected embryos. Furthermore, we compared three established methods to achieve sterility in sterlet, and we found higher embryo survival and hatching rates in CRISPR/Cas9, UV and $\mathrm{MO}$, respectively.

Keywords: Acipenser; caviar; conservation; genome editing; morpholino oligonucleotide; PGCs

\section{Introduction}

Sturgeons are an ancient fish species that have existed for at least 200 million years and are famous for their caviar [1]. Their value as a source of caviar has led sturgeons to be target of intensive legal and illegal fisheries, therefore resulting in the collapse of several sturgeon species and stocks [2,3]. Natural populations of these archaic giants have been declining due to certain factors such as water pollution and interference in their natural habitats. Other prominent impacts on the sturgeon population are hybridization, introduced species, water divergence, reduced food supply and saltwater intrusion $[4,5]$. Damming of rivers has also been proved to be detrimental to sturgeon populations because it reduces 
and/or eliminates spawning and egg/larvae habitats [6]. According to the International Union for the Conservation of Nature (IUCN 2010), 85\% of sturgeon species are at the verge of extinction. Sturgeons are generally a long living species and exhibit late onset of maturity, and a slow growth rate with infrequent reproduction [2]. Some sturgeon species have a life span over 100 years and sexual maturity is attained between 20 to 25 years or even later in females [3]. Sterlet (Acipenser ruthenus) has the fastest reproductive cycle; males mature over 3 to 7 years and females over 5 to 9 years [7], therefore making it convenient to produce donor-derived gametes of large and long maturing sturgeons. Surrogate production by the generation of germ line chimera through germ cell transplantation in various closely related species has been established in several fish species [8-16]. A germ cell free host is a pre-requisite for surrogate production, and host gonads lacking germ cells could improve transplantation efficiency, as the niche is not occupied by the endogenous germ cells and germ-line chimera only produce donor derived gametes. Triploidization is practically used in species whose triploid individuals are sterile [17-19]. Nevertheless, sturgeons are evolutionary polyploids and sterility of triploids is not yet well proved [20], therefore alternatively, other methods should be used to achieve sterility in sterlet.

Inactivation of mRNAs such as dead end ( $d n d 1)$ that is essential for formation and migration of PGCs should be done to achieve sterility experimentally, as was already shown in zebrafish, medaka, loach, goldfish and sturgeons [21-24]. Dnd1 in vertebrates binds to 3'-UTRs (untranslated regions) of germ cells specific RNAs, thus it protects them against miRNA-mediated degradation so that these RNAs can contribute to maintain the fate of PGCs $[25,26]$. Loss of $d n d 1$ in mouse also results in germ cell free sterile gonads [27]; however, in mammals, zygotic transcription replaces maternal RNA at the 1 cell stage, while in fish it occurs later during mid-blastula transition [28]. This feature affects the ability of some maternal RNAs to maintain germ cells like piwill, piwil2 and vasa that start germ cells formation in homozygous mutant fish for aforementioned genes; however, the loss of germ cells occurs at later stages [29-31]. Certain studies in fish have assayed function of $d n d 1$ when both maternal and zygotic $d n d 1$ mRNA is lost during early development [21,22,32]. Zygotic gene expression is not turned on until the onset of gastrulation in fish; and zygotic $d n d 1$ RNA in salmon was found to be required for germ cells migration to gonads [33]. In tilapia, CRISPR/Cas9 $\mathrm{KO}$ of nanos3 gene resulted in germ cell free gonads, therefore further strengthening the notion that maternally contributed factors cannot rescue germ cell development and survival [34]. Loss of germ cells in fish affects the somatic sex of gonad differently since PGCs loss leads to an all-male phenotype in medaka, zebrafish and tilapia, while both males and females develop in germ cell-free loach and goldfish [21-23,34,35]. In mice, dnd1 knock out leads to all-male offspring. It is still unclear whether or not the absence of germ cells is relevant for the differentiation of sex in sturgeons.

The latest techniques of genome editing can insert, delete and/or alter DNA sequences of cells and organisms, thus enabling scientists to dissect functions of specific genes [36]. In CRISPR/Cas9, RNA guided endonucleases (Cas9) from microbial adaptive immune system CRISPR can be easily targeted to virtually any genomic location of choice by short RNA guide. This genome editing system presents advantages over other genome editing technologies (ZFNs and TALENs) such as high efficiency, convenience and cost-effectiveness [37,38]. The CRISPR/Cas9 system therefore, is suitable to be applied in new fish models to generate sterile host by targeting the germ-cell specific candidate gene approach [26]. Previously we have used morpholino oligonucleotide (MO) against $d n d 1$ in sterlet to achieve sterility [24] and depleted PGCs from sturgeons' embryos by UV irradiation [39]; however, it needs to inject many embryos with $\mathrm{MO}$, and dechorionation is required for UV irradiation, which is laborious. In our present study, we have knocked out $d n d 1$ in sterlet by applying CRISPR/Cas9 technology. 


\section{Materials and Methods}

\subsection{Ethics Statement}

All animal experiments were conducted in accordance with the Animal Research Committee of Faculty of Fisheries and Protection of Waters in Vodňany, University of South Bohemia in České Budějovice, Czech Republic. All experimental fish were maintained according to principles based on the European Union (EU) Harmonized Animal Welfare Act of the Czech Republic, and Principles of Laboratory Animal Care and National Laws 246/1992 "Animal Welfare" on the protection of animals were followed. Experiments were approved by the Ministry of Agriculture of the Czech Republic (reference number: MSMT-12550/2016-3).

\subsection{Fish Source, Preparation of Embryos and Collection of Samples}

During the spawning season (March to June 2017), females and males of adult sterlet (Acipenser ruthenus) of five to nine years of age were transferred from outdoor ponds into recirculating aquaculture system installed indoors. Fish were kept in tanks of 4000-L and water temperature was increased to $15{ }^{\circ} \mathrm{C}$. In order to induce spermiation, male sterlet were injected with single intra-muscular injection of carp pituitary extract at $4 \mathrm{mg} / \mathrm{kg}$ body weight (BW) in $0.9 \% \mathrm{NaCl}$. Sperm collection was done $48 \mathrm{~h}$ after hormonal injection and were kept at ice at $4{ }^{\circ} \mathrm{C}$ until fertilization. Light microscopy was used to assess motility of spermatozoa that was found to be more than $80 \%$ and were used for the fertilization. Carp pituitary extract was used to stimulate the ovulation by intra-muscular injection in two doses, i.e., first dose at $0.5 \mathrm{mg} / \mathrm{kg}$ BW and second at $4.5 \mathrm{mg} / \mathrm{kg} \mathrm{BW}, 12 \mathrm{~h}$ after the first injection. Collection of ovulated eggs was done from three different females from 18 to $20 \mathrm{~h}$ after the second injection, and eggs were inseminated with sperm from two different males at $15^{\circ} \mathrm{C}$ in dechlorinated water. To remove stickiness, eggs were three times rinsed in $0.04 \%$ tannic acid. One hour later after the fertilization, chorion membrane (outer layer of eggs) was removed by using forceps. Chorion removed eggs were then transferred into $100 \mathrm{~mL}$ dechlorinated tap water with $0.01 \%$ penicillin and streptomycin in the glass petri dishes. Embryos were incubated at $15{ }^{\circ} \mathrm{C}$ in incubator. Temperature regulation was done at $15 \pm 1{ }^{\circ} \mathrm{C}$ throughout the experimental period and water was changed on daily basis. Embryos were used for injection of sgRNAs and Cas9 complex to knockout $d n d 1$, isothiocyanate (FITC)-biotin-dextran (molecular weight $=500,000)$ in order to label PGCs [40], antisense MO for the depletion of PGCs [24], UV irradiation for PGCs removal [39] and polymerase chain reaction. Embryos were kept at $-80{ }^{\circ} \mathrm{C}$ for the extraction of DNA for downstream applications.

\subsection{Cas9 Protein and $\operatorname{sg} R N A s$}

Five single guide RNAs (sgRNAs) were designed to target Acipenser ruthenus dnd1 (Ardnd1) gene. Target sites were, sgSRNA1: GGGGGGAATGCAGTCCAACC; sgRNA2: GGGGGAATGCAG TCCAACC; sgRNA3: TTCAATCATTTTCTTTCTTA; sgRNA4: TGGTTTAAAACCGTAAAGAT and sgRNA5: ATTTTCTGAGTCCATGTTTC. Oligos for sgRNAs were ordered from Macrogen Company (Macrogen Inc., Amsterdam, the Netherlands) and were annealed according to references [41,42] (Figure S1). In vitro transcription (IVT) using HiScribeTM T7 High Yield RNA synthesis kit (NEB) was used to generate sgRNAs, according to manufacturers' instructions. Synthesized sgRNAs were treated with DNAse to remove any remaining DNA traces and mySPEC spectrophotometer $\left(\right.$ VWR ${ }^{\circledR}$ mySPEC spectrophotometer) was used for sgRNAs quantification. All sgRNAs were diluted and aliquoted. Cas9 protein was purchased from PNA Bio and was re-suspended as per manufacturers' instructions, aliquoted and stored at $-80^{\circ} \mathrm{C}$.

\subsection{Microinjection of $\operatorname{sg} R A$ and Cas9 Complex}

Approximately 50 fertilized eggs of sterlet were aligned in each petri dish; in total 600 embryos were injected. Embryos at the 1 cell stage were injected with prepared complex of mixture all five sgRNAs and Cas9 protein (gRNAs+Cas9 ribonucleoprotein complex) in animal pole using a glass 
capillary needle. $1 \%$ FITC-biotin-dextran (molecular weight $=500,000)$ was co-injected in vegetal pole to label PGCs, and in the control group only 1\% FITC-biotic-dextran was injected according to Saito et al. [43]. Glass micropipette was drawn from a glass needle (Drummond, Tokyo, Japan) using a needle puller (PC-10; Narishige, Tokyo, Japan). Microinjection was done under fluorescent stereomicroscope Leica M165 FC (Leica, Wezlar, Germany) with a pressure of $100 \mathrm{hPa}$ for $\sim 1$ second. After microinjection of sgRNAs+Cas9 ribonucleoprotein complex, the survival rate and number of FITC labeled PGCs were examined at four days post fertilization (dpf). At $22 \mathrm{dpf}$, larvae were taken from each group, euthanized by using tricaine solution overdosing, body cavity of larvae was opened, dissection of the gut was performed and the position of PGCs were observed and their number was counted precisely. Embryos were kept at $15^{\circ} \mathrm{C}$, hatched larvae were fed with Tubifex. Embryo development was recorded with steromicroscope Leica M165 FC with camera (Leica DFC425C). Embryos and larvae from each group were kept in $-80^{\circ} \mathrm{C}$ for downstream applications.

\subsection{Preparation of Genomic DNA}

Control sterlet embryos and sgRNA+Cas9 ribonucleoprotein injected embryos were individually collected after $4 \mathrm{dpf}$ and $22 \mathrm{dpf}$ of injection. Total genomic DNA was isolated using a PureLink Genomic DNA Mini Kit (Invitrogen). Primers (F: GAGAGGGCAAGTTGTCTGGA; and R: AAAACCTCACAGCCAGAGGAA) were used to amplify the region of Ardnd1 gene spanning the target sites. Mutation detection assay was performed according to $[44,45]$ and Multina-500 (Shimadzu) according to reference [46] was used to detect the mutations.

\subsection{Capillary Electrophoresis and Mutation Detection Assay}

In order to perform the mutation detection assay (HMA; heteroduplex mobility assay), PCR on the genomic DNA was run over 35 cycles using KOD FX Neo (TOYOBO) and PCR products were analyzed using a microchip electrophoresis system (DNA-500 reagent kit and MCE-202 MultiNA; Shimadzu) according to Shigeta et al., 2016 [47].

\subsection{Statistical Analysis}

Statistical significance of treatments on number of PGCs was analyzed by Wilcoxon test and Kruskal-Wallis test. If there was a significant difference, thereafter we used Dunn's Post-Hoc test to find out which groups were different $(p<0.05)$. Statistical tests were performed using $\mathrm{R}$ programming language software (Version 3.5.1, 2018).

\section{Results}

\section{1. $\operatorname{sgRNA/Cas9~Ribonucleoprotein}$}

In our present study, no significant difference was observed in survival and hatching rates of embryos injected with different concentrations of gRNAs and the Cas9 protein (Figure 1A"). PGCs in FITC labeled control group and gRNAs+Cas9 ribonucleoprotein complex injected group with different concentrations of sgRNAs and Cas9 protein were counted at $4 \mathrm{dpf}$ and $22 \mathrm{dpf}$. At $4 \mathrm{dpf}$, almost no PGCs and/or a smaller number of PGCs were observed compared to the control group (Table 1, Figure 1A'). After $22 \mathrm{dpf}$, larvae from the gRNAs+Cas9 ribonucleoprotein complex injected group and control groups were euthanized and dissected and the number of PGCs was analyzed in body cavity. PGCs were found to be colonized where the genital ridge presumed to be localized (Figure 1B). gRNAs+Cas9 ribonucleoprotein complex injected group contained significantly lower number of PGCs than control group, and moreover, PGCs were not detected in dissected body cavities of crispants that were lacking PGCs at $4 \mathrm{dpf}$ (Table 2, Figure 1 $\mathrm{B}^{\prime}$ ). Intriguingly, eggs from one batch were found to be malformed such as having a cloudy structure at the region where the PGCs were supposed to have originated, when injected with sgRNA+Cas9 ribonucleoprotein (Figure 1C). These embryos did not hatch and ultimately died in chorion membrane. 
Table 1. Different concentrations of sgRNAs and Cas9 protein.

\begin{tabular}{|c|c|c|c|c|c|c|c|}
\hline Treatment & Stage & $\begin{array}{c}\text { No. of } \\
\text { Embryos/Larvae }\end{array}$ & $\begin{array}{l}\text { Min. No. } \\
\text { of PGCs }\end{array}$ & $\begin{array}{l}\text { Max. No. } \\
\text { of PGCs }\end{array}$ & Mean & SD & $p^{* * *}$ \\
\hline \multirow{2}{*}{ Control } & Neurula & 29 & 12 & 86 & 44.14 & 21.04 & \multirow{2}{*}{0.006679} \\
\hline & $22 \mathrm{dpf}$ & 14 & 12 & 41 & 26.57 & 10.30 & \\
\hline \multirow{2}{*}{$150 / 200 * *$} & Neurula & 30 & 0 & 20 & 7.23 & 5.85 & \multirow{2}{*}{0.00616} \\
\hline & $22 \mathrm{dpf}$ & 20 & 0 & 12 & 5.90 & 4.78 & \\
\hline \multirow{2}{*}{$200 / 200 * *$} & Neurula & 21 & 0 & 19 & 6.90 & 6.94 & \multirow{2}{*}{0.9672} \\
\hline & $22 \mathrm{dpf}$ & 19 & 0 & 12 & 3.68 & 4.06 & \\
\hline \multirow{2}{*}{$250 / 150 * *$} & Neurula & 21 & 0 & 21 & 7.23 & 6.70 & \multirow{2}{*}{0.6031} \\
\hline & $22 \mathrm{dpf}$ & 18 & 0 & 15 & 5.22 & 4.85 & \\
\hline
\end{tabular}

** sgRNA/Cas9 Concentrations in $\mathrm{ng} / \mu \mathrm{l}$; *** Wilcoxon test
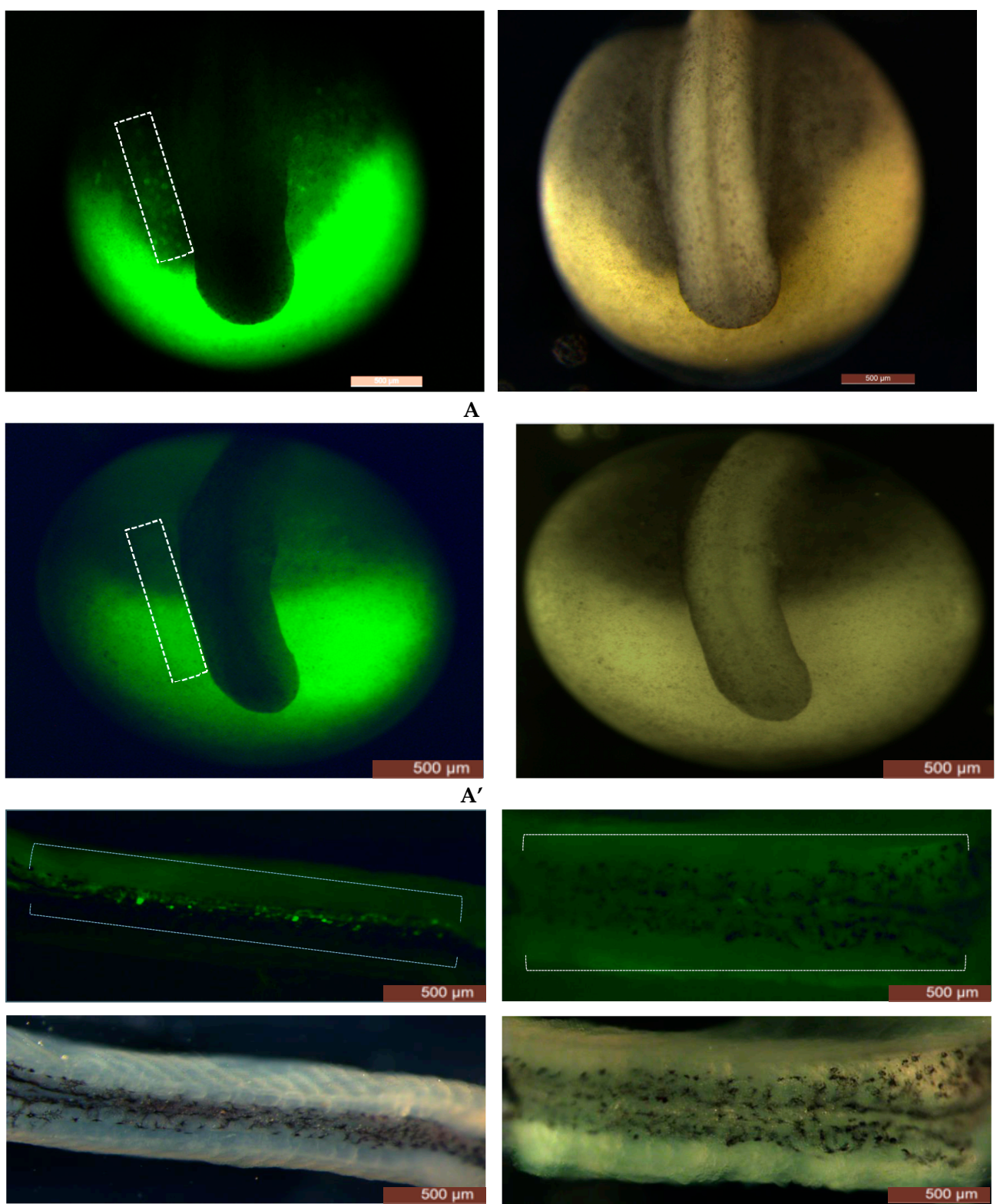

B

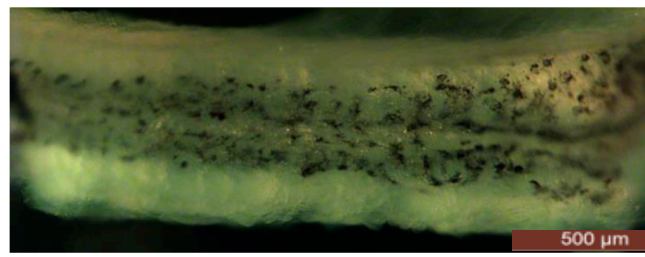

$\mathbf{B}^{\prime}$

Figure 1. Cont. 

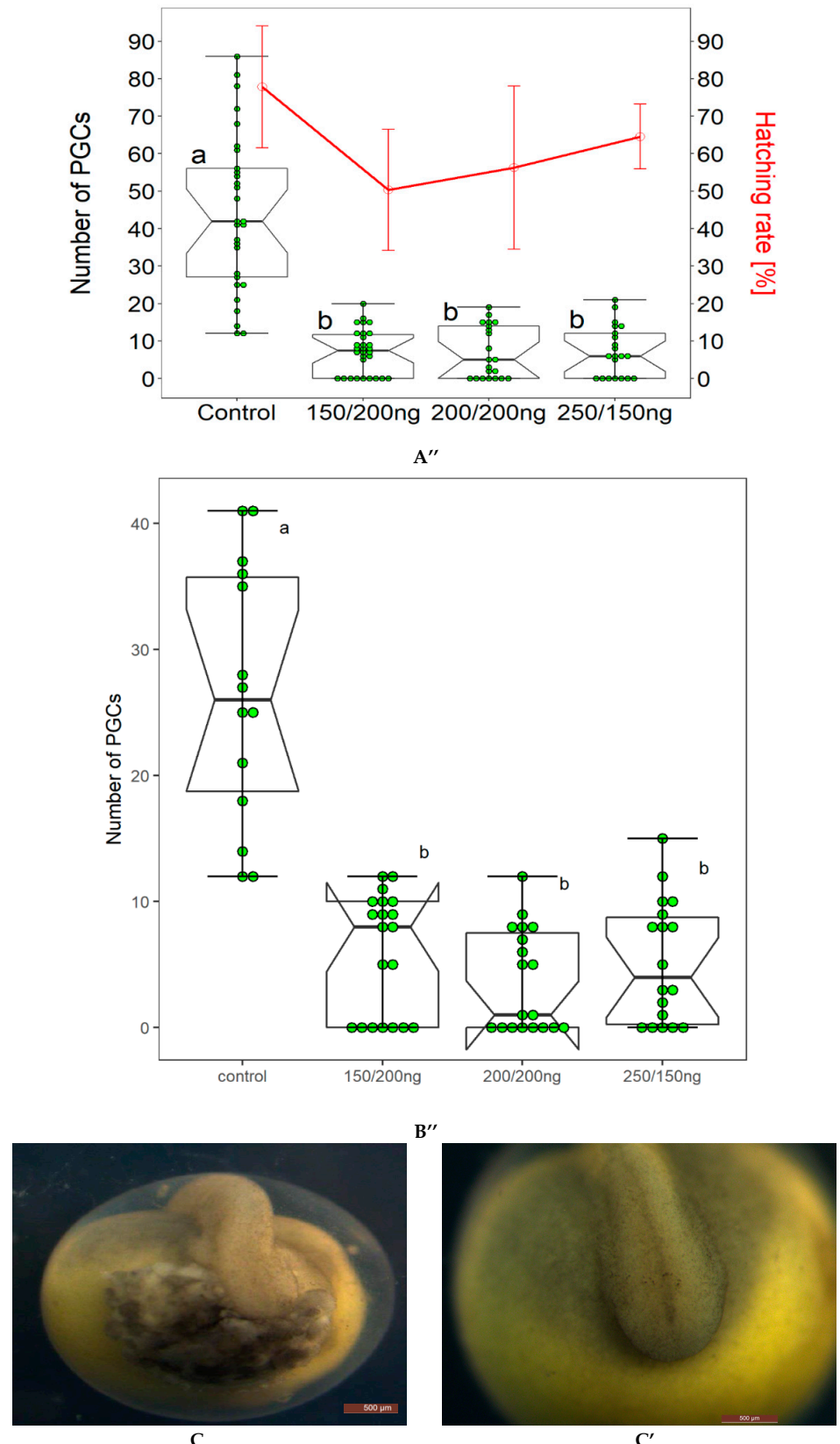

Figure 1. Number of FITC-labeled PGCs reduced from neurula stage to tail bud stage after embryos were injected with RNPs (sgRNAs+Cas9 protein). (A) Control group and RNPs injected group with FITC-dextran to label the PGCs at tail bud stage [40], respectively. Embryos injected with RNPs (A') are lacking the FITC-labeled PGCs around surround the region where tail develops; however, in control group (A) FITC-labeled PGCs can be easily seen. ( $\left.\mathbf{A}^{\prime \prime}\right)$ : Different concentrations of sgRNAs and Cas9 protein were used to find optimal concentrations; however, no significant difference of sgRNAs/Cas9 concentrations was found on FITC-labeled PGCs (box graphs). Hatching rates were also found to be insignificant (line graph). (B, $\left.\mathbf{B}^{\prime}\right)$ : In fluorescent image, many FITC-labeled PGCs can be seen in gonadal region (under a white broken line) in the control group (B); however on the contrary no FITC-labeled PGCs can be seen at the same region when injected with RNPs complex (B'; under white broken line). Number of FITC-labeled PGCs were observed by opening the body cavity of larvae, FITC-labeled PGCs were found to be in lower number when different concentrations of sgRNAs/Cas9 were used; while in the control group, FITC-labeled PGCs were found in a higher number (B"). (C) Malformed embryo at 4 dpf after the injection of RNPs (in one batch of eggs from one female) and the non-injected control group $\left(\mathbf{C}^{\prime}\right)$. The boxes with different letter show the significant difference $(p<0.05)$. 


\subsection{Comparison of CRISPR/Cas9, Dnd1-MO and UV Irradiation}

We have already successfully used the Dnd1-MO technology and UV irradiation to achieve sterility in sterlet. In our present study, we compared two aforementioned methods with CRISPR/Cas9. Dnd1-MO technology was applied according to Linhartova et al., [24]. Dnd1-MO caused complete removal of PGCs from the injected embryos (Table 2, Figure 2A); however, average lower survival and hatching rates were found in embryos and larvae at 4 and $22 \mathrm{dpf}$ (Figure 2A) as compared to the control. We then studied the effect of UV irradiation on number of FITC-labeled PGCs by exposing the embryos at $240 \mathrm{~mJ} / \mathrm{cm}^{2}$ (UV240) according to Saito et al., [39]. In group of embryos that were exposed to UV240, few ectopic FITC labeled PCCs were detected in some exposed embryos (Table 2, Figure 2A). However, most of exposed embryos were lacking the FITC-labeled PGCs in the surrounding region of the tail bud, where they were expected to accumulate. Embryos that were exposed to UV240 developed normally and grew up healthy until $22 \mathrm{dpf}$ when they were euthanized to count number of PGCs in body cavity (Figure 2B). In the CRISPR/Cas9 experiment, number of PGCs was counted at 4dpf and $22 \mathrm{dpf}$. FITC-labeled PGCs were rarely found in genital ridges of CRISPR/Cas9 treated embryos. Compared to three aforementioned methods, number of FITC-labeled PGCs at $22 \mathrm{dpf}$ in control group increased when compared those in neurula stage. No significant difference in hatching and survival rates of embryos were found in the three compared methods.

Table 2. Comparison of CRISPR/Cas9, Dnd1-MO and UV240 methods.

\begin{tabular}{|c|c|c|c|c|c|c|c|}
\hline Treatment & Stage & $\begin{array}{c}\text { No. of } \\
\text { Embryos/Larvae }\end{array}$ & $\begin{array}{c}\text { Minimum } \\
\text { No. of } \\
\text { PGCs }\end{array}$ & $\begin{array}{c}\text { Maximum } \\
\text { No. of } \\
\text { PGCs }\end{array}$ & Mean & SD & $p$ \\
\hline \multirow{2}{*}{ Control } & Neurula & 11 & 15 & 52 & 32.00 & 12.88 & \multirow{2}{*}{0.0004467} \\
\hline & $22 \mathrm{dpf}$ & 8 & 51 & 92 & 71.88 & 16.78 & \\
\hline \multirow{2}{*}{ CRISPR/Cas9 } & Neurula & 16 & 0 & 13 & 6.00 & 4.84 & \multirow{2}{*}{0.008104} \\
\hline & $22 \mathrm{dpf}$ & 11 & 0 & 5 & 1.18 & 2.04 & \\
\hline \multirow{2}{*}{ Dnd1-MO } & Neurula & 20 & 0 & 16 & 3.30 & 5.59 & \multirow{2}{*}{0.7032} \\
\hline & $22 \mathrm{dpf}$ & 9 & 0 & 12 & 5.56 & 4.77 & \\
\hline \multirow{2}{*}{ UV240 } & Neurula & 20 & 0 & 16 & 6.05 & 5.96 & \multirow{2}{*}{0.3819} \\
\hline & $22 \mathrm{dpf}$ & 19 & 0 & 18 & 4.89 & 6.13 & \\
\hline
\end{tabular}

Wilcoxon test.

\subsection{Capillary Electrophoresis and Mutation Detection Assay}

Normally developed embryos lacking PGCs were collected to examine the efficiency of disruption at on-target sites at $4 \mathrm{dpf}$. By using capillary electrophoresis some samples were found to have different band sizes (Figure 3) when compared with non-injected embryos. In mutation detection assay, different bands formation was detected in aforementioned samples, indicating that disruption of target sites occurred for Ardnd1 (Figure 3). As expected, several shorter bands were observed in embryos injected with mixture of sgRNA+Cas9 ribonucleoprotein. Injection of sgRNA+Cas9 ribonucleoprotein presumably induced frameshift mutations and/or small deletions in the $d n d 1$ gene [33,46-48]. 


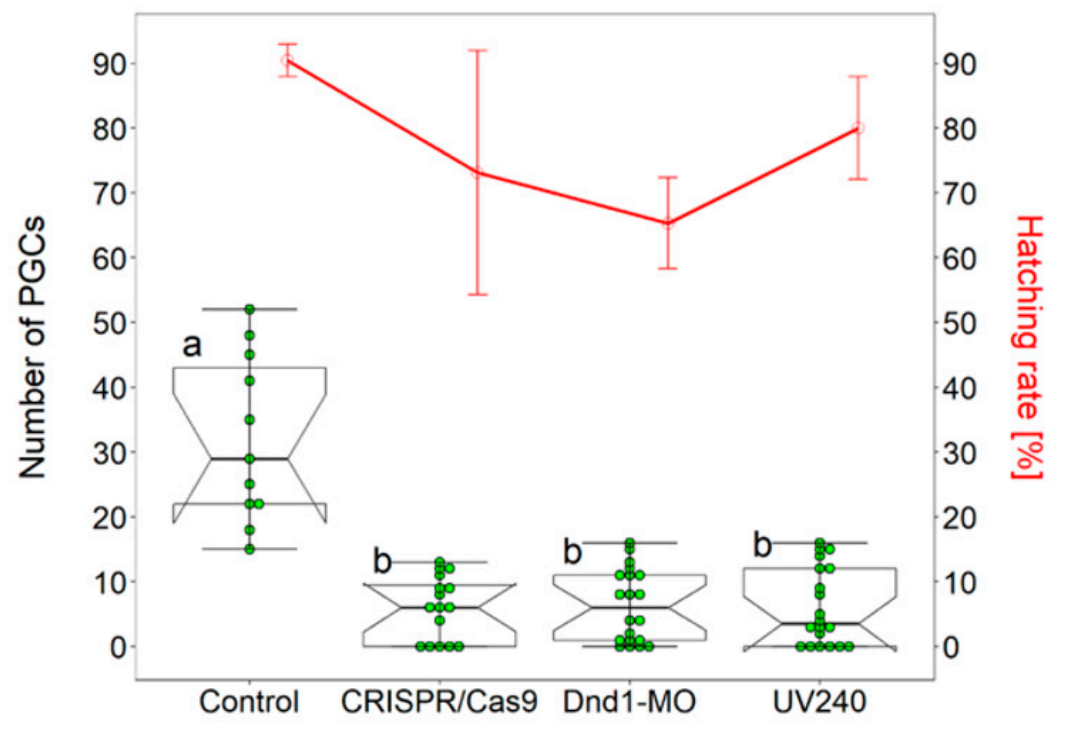

A

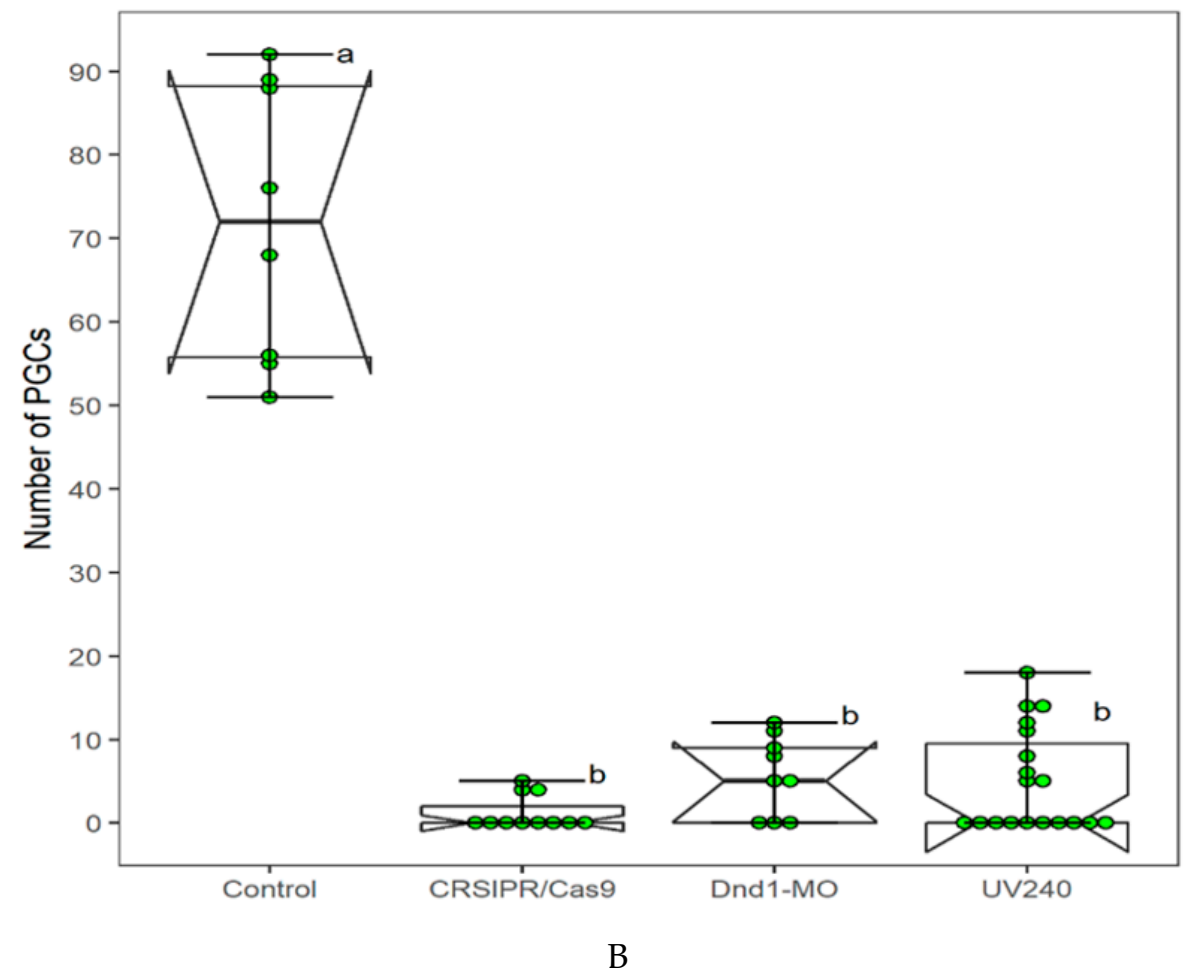

Figure 2. Three different methods to achieve sterility in sterlet (Acipenser ruthenus) have been established and were compared. (A): The control and embryos injected with CRISPR/Cas9, Dnd1-MO and UV240 exposed embryos; injected with FITC-dextran to label PGCs. Number of PGCs were counted in all three treated groups i.e., CRISPR/Cas9, Dnd1-MO and UV240, and in control group. FITC-labeled PGCs were found to be reduced at the neurula to tail bud stage (box plots). Hatching and survival rates were found to be lower in Dnd1-MO embryos (line graph) when compared to the control group. In CRISPR/Cas9 and UV240 irradiation method, hatching and survival rates of embryos did not significantly vary (line graph). The survived embryos from all three treated groups were kept and FITC-labeled PGCs were observed at $22 \mathrm{dpf}$. Number of FITC labeled PGCs continued to be absent in CRISPR/Cas9, Dnd1-MO and UV240 groups, while larvae from the control group have many FITC-labeled PGCs in the gonadal region (B). Bars with different letters signify a significant difference $(p<0.05)$. 


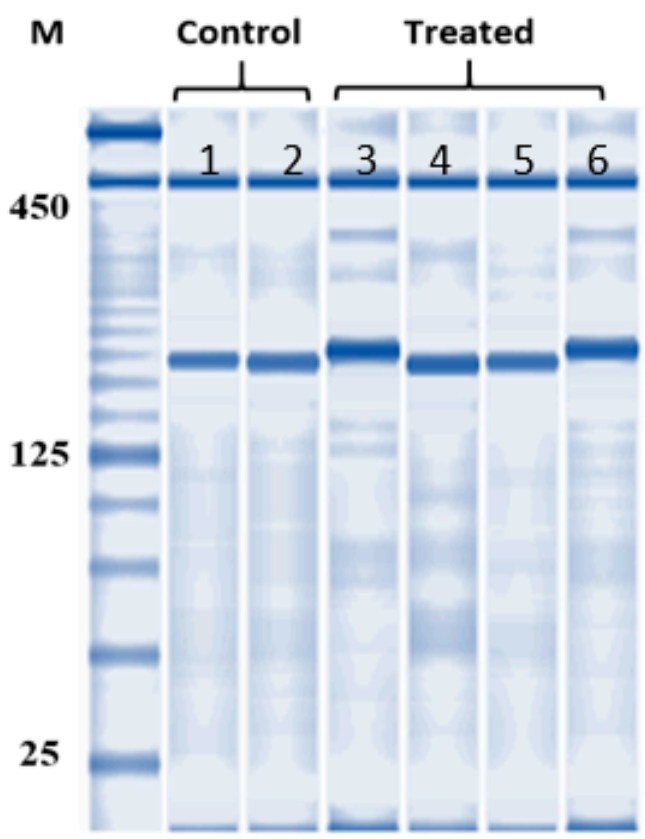

A

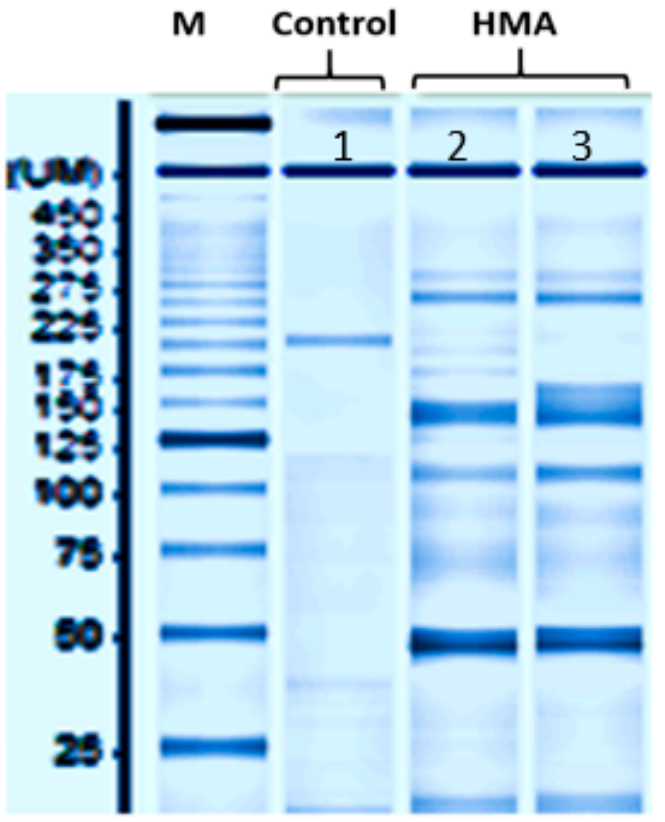

B

Figure 3. Genotyping by HMA assay in the un-injected and injected sterlet embryos. PCR products encompassing sgRNAs target sites were analyzed using a microchip electrophoresis system. (A) Bands from DNA of two injected embryos (sample number 3 and 6) were found to have different size; (B) HMA of two embryos having different bands (sample number 2 and 3). The sample 2 and 3 in Figure 3B were numbered as 3 and 6 in Figure 3A. Heteroduplex bands and multiple short bands are shown in sgRNA+Cas9 RNP injected embryos (crispants; B: sample 2 and 3).

\section{Discussion}

The majority of the genome editing studies have been conducted on polyploid species in plants such as rice (Oryza sativa), sugarcane (Saccharum spp. hybrids), Camelina sativa and Arabidopsis thaliana [49-51]. In fish model species, zebrafish, the CRISPR/Cas9 research with codon optimization of Cas9 mRNA showed induction of mutation with 75 to $99 \%$ rates in endogenous genes [52]. However, same method does not induce more than $55 \%$ mutation in sterlet, which might be due to different characteristics of embryos such as size, incubation temperature, cleavage pattern and ploidy level [53]. Interestingly, in sterlet when Cas9 protein instead of Cas9 mRNA was injected, mutation and survival rate of embryos increased by more than $90 \%$ [53]. Our present study was aimed to disrupt the Ardnd1 to achieve sterility in sterlet (Acipenser ruthenus) to prepare a host for surrogate production in critically endangered sturgeon species. This study is consistent with Chen et al., [53], suggesting that Cas9 endonuclease can be efficiently applied in sturgeon having a higher ploidy level such as hexaploid or octoploid genomes.

Microinjection is an extensively used method of gene transfer in fish species due to its low cost, ease of visualization and high efficiency [54]. We have established this method in our lab to micro-manipulate sturgeon embryos. The sgRNA+Cas9 ribonucleoprotein complex was microinjected into 1 cell stage of sterlet eggs and this was repeated several times. Survival and hatching rates of embryos varied from batch to batch of eggs and also from different females; however, the mutation rate from phenotypic evidences was stable therefore proving the reliability of CRISPR/Cas9 in sterlet. Consistent with Chen et al., [53], low toxicity to embryos was found when different concentrations of sgRNAs and Cas9 endonuclease were injected. Some malformations in embryos in region where PGCs should originate were detected at $4 \mathrm{dpf}$ in one batch of eggs from one female (Figure 1C); this is possibly because of double injection i.e., injection of sgRNA+Cas9 ribonucleoprotein complex into animal pole and FITC to label PGCs in the vegetal pole of embryos, and more likely due to off-target effects. The malformed embryos eventually died in the chorion membrane. 
As expected, the number of PGCs was reduced in CRISPR/Cas9 treated embryos when compared with control embryos, however, in contrast, a few embryos with PGCs were still detectable in larvae until $22 \mathrm{dpf}$. Possible explanation can be mosaicism and/or physiological differences among embryos. Favoring the latter explanation, there might be differences in FITC labeling efficiency among embryos due to different chorion thickness, amount and/or depth/position germ plasm in embryo and also the depth/position of germ plasm in embryo [39]. Moreover, studies have showed that maternally supplied germ plasm and PGCs number vary among embryos within the same species [55,56], and the sturgeons are consistent with these findings [40,43].

We observed a healthy development of embryos after double injection until $22 \mathrm{dpf}$. Nevertheless, to guarantee the success of production of gametes via surrogacy, it is essential to check the development of sturgeons until the adult stage. It is important to confirm that complete gonads are formed in both of the sexes. In medaka (Oryzias latipes) and zebrafish (Danio rerio), complete removal of PGCs by using $\mathrm{MO}$ against $d n d 1$ led to production of all-male population in treated embryos [21,35]. However, in other fish species such as in loach (Misgurnus anguillicaudatus) and goldfish (Carassius auratus), sterilized embryos developed into both the sexes $[22,23]$. Linhartová and colleagues used AMO- $d n d 1$ in sturgeons to generate sterile host for surrogate production; however, sex determination after PGCs removal is still unclear [24]. Therefore, sex determination should not be biased in sturgeons when preparing the host for surrogate production. We have already established methods in our laboratory to prepare a germ cell free sterlet host. In our preset study, we compared three different methods to find out which method is more suitable in terms of embryo survival and hatching rates, and the removal of PGCs. Average lower survival and hatching rates were found as compared to CRISPR/Cas9 and UV240 irradiation when Dnd1-MO was injected as it is toxic to embryos [24].

Several previous studies in fish species have studied the functions of $d n d 1$ when both maternal as well as the zygotic mRNA are lost during early development. When CRISR/Cas9 was used against dnd1 in Atlantic salmon, results showed that knockout (KO) fish were germ cell free in the F0 [33]. Thus, in the aforementioned studies, for the first time it has been revealed that CRISPR/Cas9 mediated knockouts of $d n d 1$ gene caused complete loss of the germ cells in F0 generation. Interestingly, maternal RNA was unable to compensate for loss of zygotic gene in F0 generation [33]. In sturgeons, the F0 mosaic embryos having maternal RNA compensating for zygotic gene loss could be targeted in the next generation to produce embryos having a complete loss of germ cells.

Host derived sperm or egg generation is not permitted in surrogate production technique to avoid the possibility of hybrids among offspring and consequent genetic contamination of target species. Due to complications in chromosomal pairing, interspecific hybrids of distantly related species are generally sterile. Nevertheless, hybrids of sturgeons from various species crosses tend to be viable and also fertile, even with different ploidy levels [57]. Therefore, $100 \%$ sterilization of the host is crucial in the surrogate production of sturgeons. We continue our work in this field to meet the promise that surrogate production in sturgeons is becoming feasible at a greater rate $[24,39,43,58]$. We trust that this cutting-edge technology, CRISPR/Cas9, will certainly be an invaluable tool for surrogate production of these IUCN red listed species.

\section{Conclusions}

In our present study, we have used CRISPR/Cas9 genome editing technology to achieve sterility in sterlet (Acipenser ruthenus) in order to prepare a host for surrogate production in sturgeons. The $d n d 1$ is essential for the formation and migration of PGCs in vertebrates, and its knock out in sterlet led to mismigration and/or absence of PGCs in the sterlet embryos, thus these sterile embryos can be potentially used as hosts for surrogacy in sturgeons.

Thereafter, we also compared three methods viz., Dnd1-MO, UV irradiation and CRISPR/Cas9 that have been established in our lab to sterile sterlet. In terms of removal of PGCs, no significant difference was found among the compared methods; however, higher survival and hatching rates were found in CRISPR/Cas9, UV and MO, respectively. 
Supplementary Materials: The following are available online at http://www.mdpi.com/2076-2615/9/4/174/s1, Figure S1: Generation of sgRNAs by overlap PCR.

Author Contributions: Conceptualization and methodology, A.R.B., R.F., M.R., M.P.; Data collection, A.R.B., M.F. Data processing and statistical analysis, A.R.B., T.T., M.P.; Funding acquisition, M.P.; All authors have been involved in developing, writing and commenting on the manuscript. All authors read and approved the final manuscript.

Funding: The study was financially supported by the Ministry of Education, Youth and Sports of the Czech Republic -project CENAKVA (LM2018099) and Biodiversity (CZ.02.1.01/0.0/0.0/16_025/0007370) and the Czech Science Foundation (grant number 17-19714Y), by the European Union's Horizon 2020 research and innovation program under the Marie Sklodowska-Curie grant agreement No. 642893 (IMPRESS).

Acknowledgments: The authors are grateful to all lab members of Laboratory of Germ Cells, Faculty of Fisheries and Protections of Waters, University of South Bohemia in Ceske Budejovice for their help during the experiments.

Conflicts of Interest: No conflict of interest exits among the authors.

\section{References}

1. Bemis, W.E.; Kynard, B. Sturgeon rivers: An introduction to acipenseriform biogeography and life history. Environ. Biol. Fish. 1997, 167-183. [CrossRef]

2. Pikitch, E.K.; Doukakis, P.; Laucks, L.; Chakrabarty, P.; Erickson, D.L. Status, trends and management of sturgeon and paddlefish fisheries. Fish. Fish. 2005, 6, 233-265. [CrossRef]

3. Billard, R.; Guillaume, L. Biology and conservation of sturgeon and paddlefish. Rev. Fish. Biol. Fish. 2001, 1, 355-392.

4. Ludwig, A.; Belfiore, N.M.; Pitra, C.; Svirsky, V.; Jenneckens, I. Genome duplication events and functional reduction of ploidy levels in sturgeon (Acipenser, Huso and Scaphirhynchus). Genetics 2001, 158, 1203-1215. [PubMed]

5. Zhang, H.; Wei, Q.W.; Kyanrd, B.E.; Du, H.; Yang, D.G.; Chen, X.H. Spatial structure and bottom characteristics of the only remaining spawning area of Chinese sturgeon in the Yangtze River. J. Appl. Ichthyol. 2011, 27, 251-256. [CrossRef]

6. Hildebrand, L.; McLeod, C.; McKenzie, S. Status and management of white sturgeon in the Columbia River in British Columbia, Canada: An overview. J. Appl. Ichthyol. 1999, 15, 164-172. [CrossRef]

7. Dettlaff, T.A.; Ginsburg, A.S.; Schmalhausen, O.I. Sturgeon Fishes: Developmental Biology and Aquaculture; Springer-Verlag: New York, NY, USA, 1993.

8. Saito, T.; Goto-Kazeto, R.; Arai, K.; Yamaha, E. Xenogenesis in teleost fish through generation of germ-line chimeras by single primordial germ cell transplantation. Biol. Reprod. 2008, 78, 159-166. [CrossRef]

9. Morita, T.; Morishima, K.; Miwa, M.; Kumakura, N.; Kudo, S.; Ichida, K.; Mitsuboshi, T.; Takeuchi, Y.; Yoshizaki, G. Functional sperm of the yellowtail (Seriola quinqueradiata) were produced in the small-bodied surrogate, jack mackerel (Trachurus japonicus). Mar. Biotechnol. 2015, 17, 644-654. [CrossRef]

10. Yoshizaki, G.; Lee, S. Production of live fish derived from frozen germ cells via germ cell transplantation. Stem Cell Res. 2018, 29, 103-110. [CrossRef]

11. Lujić, J.; Marinović, Z.; Bajec, S.S.; Djurdjevič, I.; Urbányi, B.; Horváth, Á. Interspecific germ cell transplantation: A new light in the conservation of valuable Balkan trout genetic resources? Fish. Physiol. Biochem. 2018, 44, 1487-1498. [CrossRef]

12. Yazawa, R.; Takeuchi, Y.; Morita, T.; Ishida, M.; Yoshizaki, G. The Pacific bluefin tuna (Thunnus orientalis) dead end gene is suitable as a specific molecular marker of type A spermatogonia. Mol. Reprod. Dev. 2013, 80, 871-880. [CrossRef] [PubMed]

13. Yazawa, R.; Takeuchi, Y.; Higuchi, K.; Yatabe, T.; Kabeya, N.; Yoshizaki, G. Chub mackerel gonads support colonization, survival, and proliferation of intraperitoneally transplanted xenogenic germ cells. Biol. Reprod. 2010, 82, 896-904. [CrossRef] [PubMed]

14. Pšenička, M.; Saito, T.; Linhartová, Z.; Gazo, I. Isolation and transplantation of sturgeon early-stage germ cells. Theriogenology 2015, 83, 1085-1092. [CrossRef]

15. Higuchi, K.; Takeuchi, Y.; Miwa, M.; Yamamoto, Y.; Tsunemoto, K.; Yoshizaki, G. Colonization, proliferation, and survival of intraperitoneally transplanted yellowtail Seriola quinqueradiata spermatogonia in nibe croaker Nibea mitsukurii recipient. Fish. Sci. 2011, 77, 69-77. [CrossRef] 
16. Pacchiarini, T.; Sarasquete, C.; Cabrita, E. Development of interspecies testicular germ-cell transplantation in flatfish. Reprod. Fertil. Dev. 2014, 26, 690-702. [CrossRef]

17. Bar, I.; Smith, A.; Bubner, E.; Yoshizaki, G.; Takeuchi, Y.; Yazawa, R.; Chen, B.N.; Cummins, S.; Elizur, A. Assessment of yellowtail kingfish (Seriola lalandi) as a surrogate host for the production of southern bluefin tuna (Thunnus maccoyii) seed via spermatogonial germ cell transplantation. Reprod. Fertil. Dev. 2015, 28, 2051-2064. [CrossRef] [PubMed]

18. Hamasaki, M.; Takeuchi, Y.; Yazawa, R.; Yoshikawa, S.; Kadomura, K.; Yamada, T.; Miyaki, K.; Kikuchi, K.; Yoshizaki, G. Production of tiger puffer Takifugu rubripes offspring from triploid grass puffer Takifugu niphobles parents. Mar. Biotechnol. 2017, 19, 579-591. [CrossRef]

19. Okutsu, T.; Shikina, S.; Kanno, M.; Takeuchi, Y.; Yoshizaki, G. Production of trout offspring from triploid salmon parents. Science 2007, 317, 1517. [CrossRef]

20. Havelka, M. Molecular Aspects of Interspecific Hybridization of Sturgeons Related to Polyploidy and In Situ Conservation. Ph.D. Thesis, University of South Bohemia in Ceské Budejovice, Faculty of Fisheries and Protection of Waters, České Budějovice, Czech Republic, 2013.

21. Kurokawa, H.; Saito, D.; Nakamura, S.; Katoh-Fukui, Y.; Ohta, K.; Baba, T.; Morohashi, K.-I.; Tanaka, M. Germ cells are essential for sexual dimorphism in the medaka gonad. Proc. Natl. Acad. Sci. USA 2007, 104, 16958-16963. [CrossRef]

22. Fujimoto, T.; Nishimura, T.; Goto-Kazeto, R.; Kawakami, Y.; Yamaha, E.; Arai, K. Sexual dimorphism of gonadal structure and gene expression in germ cell-deficient loach, a teleost fish. Proc. Natl. Acad. Sci. USA 2010, 107, 17211-17216. [CrossRef]

23. Goto, R.; Saito, T.; Takeda, T.; Fujimoto, T.; Takagi, M.; Arai, K.; Yamaha, E. Germ cells are not the primary factor for sexual fate determination in goldfish. Dev. Biol. 2012, 370, 98-109. [CrossRef] [PubMed]

24. Linhartová, Z.; Saito, T.; Kaspar, V.; Rodina, M.; Praskova, E.; Hagihara, S.; Pšenička, M. Sterilization of sterlet Acipenser ruthenus by using knock-down agent, antisense morpholino oligonucleotide, against dead end gene. Theriogenology 2015, 84, 1246-1255. [CrossRef]

25. Kedde, M.; Strasser, M.J.; Boldajipour, B.; Oude Vrielink, J.A.; Slanchev, K.; le Sage, C.; Nagel, R.; Voorhoeve, P.M.; van Duijse, J.; Ørom, U.A.; et al. RNA-Binding Protein Dnd1 Inhibits MicroRNA Access to Target mRNA. Cell 2007, 131, 1273-1286. [CrossRef] [PubMed]

26. Baloch, A.R.; Franěk, R.; Saito, T.; Pšenička, M. Dead-end (DND) protein in fish-a review. Fish. Physiol. Biochem. 2019. [CrossRef]

27. Youngren, K.K.; Coveney, D.; Peng, X.; Bhattacharya, C.; Schmidt, L.S.; Nickerson, M.L.; Lamb, B.T.; Deng, J.M.; Behringer, R.R.; Capel, B.; et al. The Ter mutation in the dead end gene causes germ cell loss and testicular germ cell tumours. Nature 2005, 435, 360. [CrossRef] [PubMed]

28. Schier, F. The maternal-zygotic transition: Death and birth of RNAs. Science 2007, 316, 406-407. [CrossRef]

29. Houwing, S.; Kamminga, L.M.; Berezikov, E.; Cronembold, D.; Girard, A.; van den Elst, H.; Filippov, D.V.; Blaser, H.; Raz, E.; Moens, C.B.; et al. A role for Piwi and piRNAs in germ cell maintenance and transposon silencing in Zebrafish. Cell 2007, 129, 69-82. [CrossRef]

30. Houwing, S.; Berezikov, E.; Ketting, R.F. Zili is required for germ cell differentiation and meiosis in zebrafish. EMBO J. 2008, 27, 2702-2711. [CrossRef]

31. Hartung, O.; Forbes, M.M.; Marlow, F.L. Zebrafish vasa is required for germ-cell differentiation and maintenance. Mol. Reprod. Dev. 2014, 81, 946-961. [CrossRef]

32. Weidinger, G.; Stebler, J.; Slanchev, K.; Dumstrei, K.; Wise, C.; Lovell-Badge, R.; Thisse, C.; Thisse, B.; Raz, E. dead end, a novel vertebrate germ plasm component, is required for zebrafish primordial germ cell migration and survival. Curr. Biol. 2003, 13, 1429-1434. [CrossRef]

33. Wargelius, A.; Leininger, S.; Skaftnesmo, K.O.; Kleppe, L.; Andersson, E.; Taranger, G.L.; Schulz, R.W.; Edvardsen, R.B. Dnd knockout ablates germ cells and demonstrates germ cell independent sex differentiation in Atlantic salmon. Sci. Rep. 2016, 6, 21284. [CrossRef] [PubMed]

34. Li, M.; Yang, H.; Zhao, J.; Fang, L.; Shi, H.; Li, M.; Sun, Y.; Zhang, X.; Jiang, D.; Zhou, L.; et al. Efficient and Heritable Gene Targeting in Tilapia by CRISPR/Cas9. Genetics 2004, 197, 591-599. [CrossRef]

35. Slanchev, K.; Stebler, J.; de la Cueva-Mendez, G.; Raz, E. Development without germ cells: The role of the germ line in zebrafish sex differentiation. Proc. Natl. Acad. Sci. USA 2005, 102, 4074-4079. [CrossRef] [PubMed] 
36. Hsu, P.D.; Lander, E.E.; Zhang, F. Development and Applications of CRISPR-Cas9 for Genome Engineering. Cell 2014, 157, 1262-1278. [CrossRef] [PubMed]

37. Blitz, I.L.; Biesinger, J.; Xie, X.; Cho, K.W.Y. Biallelic genome modification in F0 Xenopus tropicalis embryos using the CRISPR/Cas system. Genesis 2013, 51, 827-834. [CrossRef]

38. Nakayama, T.; Blitz, I.L.; Fish, M.B.; Odeleye, A.O.; Manohar, S.; Cho, K.W.; Grainger, R.M. Cas9-Based Genome Editing in Xenopus tropicalis. Methods Enzymol. 2014, 546, 355-375. [PubMed]

39. Saito, T.; Guralp, H.; Iegorova, V.; Rodina, M.; Pšenička, M. Elimination of primordial germ cells in sturgeon embryos by ultraviolet irradiation. Biol. Reprod. 2018, 99, 556-564. [CrossRef]

40. Saito, T.; Pšenička, M. Novel technique for visualizing primordial germ cells in sturgeons (Acipenser ruthenus, A. gueldenstaedtii, A. baerii, and Huso huso). Biol. Reprod. 2015, 115, 128314. [CrossRef]

41. Gagnon, J.A.; Valen, E.; Thyme, S.B.; Huang, P.; Akhmetova, L.; Pauli, A.; Montague, T.G.; Zimmerman, S.; Richter, C.; Schier, A.F. Efficient Mutagenesis by Cas9 Protein-Mediated Oligonucleotide Insertion and Large-Scale Assessment of Single-Guide RNAs. PLoS ONE 2014, 9, e106396. [CrossRef]

42. Naert, T.; Colpaert, R.; Van Nieuwenhuysen, T.; Dimitrakopoulou, D.; Leoen, J.; Haustraete, J.; Boel, A.; Steyaert, W.; Lepez, T.; Deforce, D.; et al. CRISPR/Cas9 mediated knockout of $r b 1$ and $r b l 1$ leads to rapid and penetrant retinoblastoma development in Xenopus tropicalis. Sci. Rep. 2016, 6, 35264. [CrossRef]

43. Saito, T.; Pšenička, M.; Goto, R.; Inoue, K.; Adachi, S.; Arai, K.; Yamaha, E. The origin and migration of primordial germ cells in sturgeons. PLoS ONE 2014, 9, e86861. [CrossRef] [PubMed]

44. Ota, S.; Hisano, Y.; Muraki, M.; Hoshijima, K.; Dahlem, T.J.; Grunwald, D.J.; Okada, Y.; Kawahara, A. Efficient identification of TALEN-mediated genome modifications using heteroduplex mobility assays. Genes Cells 2013, 18, 450-458. [CrossRef] [PubMed]

45. Ota, S.; Taimatsu, K.; Yanagi, K.; Namiki, T.; Ohga, R.; Higashijima, S.; Kawahara, A. Functional visualization and disruption of targeted genes using CRISPR/Cas9-mediated eGFP reporter integration in zebrafish. Sci. Rep. 2016, 6, 34991. [CrossRef]

46. Sakane, Y.; Iida, M.; Hasebe, T.; Fujii, S.; Buchholz, D.R.; Ishizuya-Oka, A.; Yamamoto, T.; Suzuki, K.T. Functional analysis of thyroid hormone receptor beta in Xenopus tropicalis founders using CRISPR-Cas. Biol. Open 2018, 7, bio030338. [CrossRef]

47. Shigeta, M.; Sakane, Y.; Iida, M.; Suzuki, M.; Kashiwagi, K.; Kashiwagi, A.; Fujii, S.; Yamamoto, T.; Suzuki, K.T. Rapid and efficient analysis of gene function using CRISPR-Cas9 in Xenopus tropicalis founders. Genes Cells 2016, 21, 755-771. [CrossRef] [PubMed]

48. Radev, Z.; Hermel, J.-M.; Elipot, Y.; Bretaud, S.; Arnould, S.; Duchateau, P.; Ruggiero, F.; Joly, J.S.; Sohm, F. A TALEN-Exon Skipping Design for a Bethlem Myopathy Model in Zebrafish. PLoS ONE 2015, 7, e0133986. [CrossRef]

49. Shan, Q.; Wang, Y.; Li, J.; Zhang, Y.; Chen, K.; Liang, Z.; Zhang, K.; Liu, J.; Xi, J.J.; Qiu, J.L.; et al. Targeted genome modification of crop plants using a CRISPR-Cas system. Nat. Biotechnol. 2013, 31, 686-688. [CrossRef] [PubMed]

50. Jung, J.H.; Altpeter, F. TALEN mediated targeted mutagenesis of the caffeic acid O-methyltransferase in highly polyploidy sugarcane improves cell wall composition for production of bioethanol. Plant Mol. Biol. 2016, 92, 131-142. [CrossRef]

51. Aznar-Moreno, J.A.; Durrett, T.P. Simultaneous targeting of multiple gene homeologs to alter seed oil production in Camelina sativa. Plant Cell Physiol. 2017, 58, 1260-1267. [CrossRef]

52. Jao, L.E.; Wente, S.R.; Chen, W. Efficient multiplex biallelic zebrafish genome editing using a CRISPR nuclease system. Proc. Natl. Acad. Sci. USA 2013, 110, 13904-13909. [CrossRef]

53. Chen, J.; Wang, W.; Tian, Z.; Dong, Y.; Dong, T.; Zhu, H.; Zhu, Z.; Hu, H.; Hu, W. Efficient Gene Transfer and Gene Editing in Sterlet (Acipenser ruthenus). Front. Genet. 2018, 9, 117. [CrossRef] [PubMed]

54. Tonelli, F.M.P.; Lacerda, S.M.S.N.; Tonelli, F.C.P.; Costa, G.M.J.; de França, L.R.; Resende, R.R. Progress and biotechnological prospects in fish transgenesis. Biotechnol. Adv. 2017, 35, 832-844. [CrossRef] [PubMed]

55. Saito, T.; Otani, S.; Fujimoto, T.; Suzuki, T.; Nakatsuji, T.; Arai, K.; Yamaha, E. The germ line lineage in ukigori, Gymnogobius species (Teleostei: Gobiidae) during embryonic development. Int. J. Dev. Biol. 2004, 48, 1079-1085. [CrossRef]

56. Fujimoto, T.; Kataoka, T.; Sakao, S.; Saito, T.; Yamaha, E.; Arai, K. Developmental stages and germ cell lineage of the loach (Misgurnus anguillicaudatus). Zool. Sci. 2006, 23, 977-989. [CrossRef] [PubMed] 
57. Havelka, M.; Kaspar, V.; Hulak, M.; Flajshans, M. Sturgeon genetics and cytogenetics: A review related to ploidy levels and interspecific hybridization. Folia Zool. 2011, 60, 93-103. [CrossRef]

58. Pšenička, M.; Saito, T.; Rodina, M.; Dzyuba, B. Cryopreservation of early stage Siberian sturgeon Acipenser baerii germ cells, comparison of whole tissue and dissociated cells. Cryobiology 2016, 72, 119-122. [CrossRef] [PubMed]

(C) 2019 by the authors. Licensee MDPI, Basel, Switzerland. This article is an open access article distributed under the terms and conditions of the Creative Commons Attribution (CC BY) license (http://creativecommons.org/licenses/by/4.0/). 